\title{
BANTUAN PEMBANGUNAN RUSUNAWA PADA LEMBAGA PENDIDIKAN TINGGI
}

\author{
Dr. Raflis, ST.,M.Si \\ Program Studi Magister Perencanaan Wilayah \\ Universitas Batam \\ Email: ' tanjung.raflis@gmail.com
}

With the issuance of Law Number 16 of 1985 concerning Flats, Draft General Guidelines for Compilation and Submission of Proposals for Development of Flats for Higher Education Number 1 of 2006 and Regulation of the State Minister of Public Housing Number 9/PERMEN/M/2008 concerning Guidelines for Assistance for Flats Development Simple rent (Rusunawa) at Higher Education Institutions and Boarding Education Institutions, so students can breathe a little easier to reduce the cost of education. The purpose of this study is to determine the effectiveness of the use of flats in universities. The research approach used in this research is a quantitative approach and a qualitative approach. Quantitative methods emphasize the existence of variables as objects of research and these variables must be defined in the form of the operationalization of each variable. This research is an ex facto research because it is carried out after all events have taken place. The results of this study indicate that so far the utilization of the building has not been optimal. This is because the building design does not match the habits of building users, even though the building design is a uniform design from the rusunawa construction aid provider. Moreover, other regions have different local wisdom according to the characteristics of each region.

Keywords: Effectiveness, Policy Implementation, Student Flats.

Dengan dikeluarkannya Undang-undang Nomor 16 Tahun 1985 tentang Rumah Susun, Rancangan Pedoman Umum Penyusunan dan Pengajuan Usulan Bantuan Pembangunan Rusunawa pada Perguruan Tinggi Nomor 1 Tahun 2006 dan Peraturan Menteri Negara Perumahan Rakyat Nomor 9/PERMEN/M/2008 tentang Pedoman Bantuan Pembangunan Rumah Susun Sederhana Sewa (Rusunawa) pada Lembaga Pendidikan Tinggi dan Lembaga Pendidikan Berasrama, maka mahasiswa dapat bernafas lega sedikit guna meringankan biaya pendidikan. Tujuan dari studi ini adalah untuk mengetahui efektifitas pemanfaatan bangunan rusunawa pada perguruan tinggi. Pendekatan penelitian yang digunakan dalam penelitian ini adalah pendekatan kuantitatif dan pendekatan kualitatif. Metode kuantitatif mementingkan adanya variabel-variabel sebagai obyek penelitian dan variabel-variabel tersebut harus didefinisikan dalam bentuk operasionalisasi masing-masing variabel. Penelitian ini merupakan penelitian ex facto karena dilakukan setelah semua kejadian selesai berlangsung.Hasil dari penelitian ini menunjukkan bahwa sejauh ini pemanfaatan bangunan belum cukup optimal. Hal ini dikarenakan desain bangunan yang kurang cocok dengan kebiasaan pengguna bangunan, padahal desain bangunan merupakan penyeragaman desain dari pigak pemberi bantuan pembangunan rusunawa. Apalagi lain daerah mempunyai kearifan lokal yang berbeda-beda pula sesuai dengan karakteristik daerah masing-masing.

Kata Kunci: Efektifitas, Implementasi Kebijakan, Rusunawa Mahasiswa.

\section{PENDAHULUAN}

Dengan dikeluarkannya Undang-undang Nomor 16 Tahun 1985 tentang Rumah Susun dan Peraturan Menteri Negara Perumahan Rakyat Nomor 9/PERMEN/M/2008 tentang Bantuan Pembangunan Rumah Susun Sederhana
Sewa (Rusunawa) pada Lembaga Pendidikan Tinggi dan Lembaga Pendidikan Berasrama, maka mahasiswa dapatlah bernafas lega sedikit guna meringkankan biaya pendidikan. Bantuan pembangunan rusunawa adalah bantuan pembangunan fisik maupun pembangunan baru 
Rumah Susun Sederhana Sewa (Rusunawa), maupun rehabilitasi asrama/hunian yang telah ada dan dibiayai oleh Pemerintah melalui APBN pada Kementrian Negara Perumahan Rakyat dan pada Kementrian terkait lainnya. Bantuan Pembangunan Rusunawa dimaksudkan untuk memberikan fasilitas bantuan fisik bangunan Rusunawa sehingga mendorong lembaga pendidikan tinggi dan/atau lembaga pendidikan berasrama untuk memenuhi kebutuhan asrama bagi mahasiswa/siswa/santri dan hunian bagi pendidik dan/atau tenaga kependidikan dan bertujuan sebagai pedoman bagi Pemerintah, pemerintah daerah, penyelenggara pendidikan dalam mengajukan usulan bantuan pembangunan Rusunawa.

Beberapa perguruan tinggi di kota Medan telah menerima bantuan pembangunan rusunawa mahasiswa sejak dikeluarkannya kebijakan tentang bantuan pembangunan rusunawa bagi lembaga pendidikan tinggi. Namun pada kenyataannya, beberapa bangunan rusunawa yang telah selesai dibangun tidak dimanfaatkan dengan optimal (Tanjung, 2011).

Secara harfiah, ilmu kebijaksanaan adalah terjemahan langsung dari policy science (Dror dalam Alie, 2006), sementara penulis- penulis terkenal lainnya seperti William Dunn, Charles Jones, Lee Friedman dan lain-lain menggunakan istilah public policy dan public policy analysis. Namun perbedaan istilah dalam menterjemahkan kata kebijaksanaan dan kebijakan ini tidaklah menjadi masalah selama kedua istilah ini diartikan sebagai suatu keputusan pemerintah yang relatif bersifat umum dan ditujukan kepada masyarakat umum (Abidin, 2006).

Implementasi kebijakan pada prinsipnya adalah cara agar sebuah kebijakan dapat mencapai tujuannya. Untuk mengimplementasikan kebijakan, maka ada dua pilihan langkah yang ada yaitu langsung mengimplementasikan dalam bentuk programprogram atau melalui formulasi kebijakan derivat atau turunan dari kebijakan tersebut (Dwijowijoto, 2003).

\section{METODE PENELITIAN}

Metode yang digunakan untuk mencapai tujuan yang ingin dicapai dalam penelitian ini adalah metode penelitian kuantitatif dan kualitatif

1.Data Primer

Data primer adalah merupakan data yang banyak diperoleh dari sumber/obyek penelitian langsung baik itu bersifat wawancara. Wawancara dilakukan dengan cara berbicara langsung kepada obyek/responden dengan tetap mengacu kepada daftar pertanyaan yang telah dibuat sebelumnya. Wawancara dilaksanakan kepada pengelola rusunawa dan pihak lembaga pendidikan tinggi yang menangani masalah rusunawa mahasiswa.

\section{Data Sekunder}

Data sekunder diperoleh dari pihak terkait yang berwenang dalam mengimplementasikan kebijakan bantuan pembangunan rusunawa pada lembaga pendidikan tinggi. Dalam hal ini pihak yang dimaksud adalah pihak Kementrian Negara Perumahan Rakyat sebagai lembaga yang memberikan bantuan pembangunan rusunawa pada lembaga pendidikan tinggi.

Responden yang akan dipilih dalam penelitian ini terdiri dari pihak perguruan tinggi yang mengajukan bantuan pembangunan rusunawa mahasiswa. Data-data kuantitatif diperoleh dengan menggunakan teknik probability sampling. Probability sampling adalah suatu teknik pengambilan sampel dengan memberikan peluang yang sama kepada setiap populasi untuk dipilih menjadi anggota sampel (Akon dan Riduwan, 2009).

Untuk mengorganisasikan, mengelompokkan dan mengurutkan data menjadi suatu pola, kategori dan satuan uraian dasar sesuai dengan kebutuhan data yang diinginkan maka dibuatlah suatu kerangka analisis. Kerangka analisis terdiri dari 3 (tiga) variabel penting di dalamnya. Variabel ini adalah:

1. Input, merupakan variabel dari sasaran yang diinginkan. Dalam penelitian ini, input yang dimaksud adalah kebijakan yang menyangkutmasalah bantuan pembangunan rusunawa pada lembaga pendidikan tinggi, meliputi: 
a. UU No. 16 Tahun 1985 tentang Rumah Susun;

b. Rancangan Pedoman Umum

Penyusunan dan Pengajuan Usulan

Pembangunan Rusunawa pada Perguruan Tinggi

No. 1 Tahun 2006;

c. Peraturan Menteri Negara Perumahan Rakyat No 9/PERMEN/M/2008 tentang Pedoman

Bantuan Pembangunan Rumah Susun Sederhana Sewa pada Lembaga Pendidikan Tinggi dan Lembaga Pendidikan Berasrama.

1. Proses, yang digunakan menggunakan skala Likert. Skala Likert digunakan untuk mengukur sikap, pendapat, dan persepsi seseorang atau sekelompok orang tentang fenomena sosial.

2. Output, merupakan hasil akhir dari analisis terhadap data yang diperoleh. Hasil yang diperoleh dari output ini dianalisa sehingga menjadi kesimpulan dan rekomendasi terhadap hasil penelitian.

\section{HASIL DAN PEMBAHASAN}

1. Analisa Terhadap Penerapan Kebijakan di Lapangan Kriteria Pemilihan Daerah Prioritas merupakan alat seleksi bagi Kementrian Negara Perumahan Rakyat untuk memilih usulan atau proposal pembangunan rusunawa yang diusulkan oleh perguruan tinggi, hal inipun harus dilakukan dikarenakan keterbatasan dana yang tersedia dalam APBN menjadikan program penyediaan rusunawa ini menjadi sangat terbatas sehingga pemilihan lokasi program ditentukan melalui skema kompetisi dalam pemilihan daerah prioritas. Proposal bantuan pembangunan rusunawa mahasiswa dari pihak Universitas Medan Area kepada Kementrian Negara Perumahan Rakyat diajukan pada bulan April 2007. Setelah melalui penilaian dari pihak Kementrian, Universitas Medan Area termasuk dalam salah satu perguruan tinggi yang memperoleh bantuan pembangunan rusunawa mahasiswa pada tahun tersebut. Namun kenyataan di lapangan, bantuan tersebut baru bisa diberikan pada tahun berikutnya yaitu tahun 2008 karena dana APBN yang sedianya akan digunakan untuk bantuan pembangunan rusunawa mahasiswa dialihkan ke pekerjaan Banjir Kanal Timur di Jakarta. Seperti halnya pengajuan proposal rusunawa USU, pengajuan proposal rusunawa UMA telah memenuhi segala ketentuan yang ditetapkan dalam Peraturan Menteri Negara Perumahan Rakyat No. 8/PERMEN/M/2006 tentang Pedoman Bantuan Pembangunan Rumah Susun Sewa Sederhana pada Lembaga Pendidikan Tinggi dan Lembaga Pendidikan Berasrama.

Kesimpulan yang didapat oleh penulis terhadap analisa proses permohonan bantuan pembangunan rusunawa mahasiswa, ketiga perguruan tinggi yang menerima bantuan pembangunan rusunawa mahasiswa telah memenuhi persyaratan yang ditentukan dalam Peraturan Menteri Negara Perumahan Rakyat Nomor Nomor 9/PERMEN/M/2008 tentang Bantuan Pembangunan Rumah Susun Sederhana Sewa (Rusunawa) pada Lembaga Pendidikan Tinggi dan Lembaga Pendidikan Berasrama.

Setelah perguruan tinggi mengajukan proposal kepada Kementrian Negara Perumahan Rakyat, maka dilakukan verifikasi. Verifikasi dilakukan terhadap usulan bantuan pembangunan rusunawa, dilakukan oleh tim verifikasi yang ditetapkan dengan Keputusan Deputi Bidang Perumahan Formal. Tim verifikasi ini terdiri dari:

1. Kedeputian Bidang Perumahan Formal;

2. Sekretariat Kementerian Negara Perumahan Rakyat;

3. Pusat Pengembangan Perumahan.

Selain anggota yang tersebut di atas, keanggotaan tim verifikasi dapat melibatkan unsur-unsur instansi lain yang terkait.

Hasil penilaian verifikasi administrasi usulan bantuan pembangunan Rusunawa diajukan kepada Menteri untuk ditetapkan sebagai calon penerima bantuan pembangunan Rusunawa. Penetapan calon penerima bantuan ditindaklanjuti oleh tim verifikasi dengan melakukan verifikasi lapangan. Hasil penilaian verifikasi lapangan diajukan kepada Menteri untuk ditetapkan sebagai penerima bantuan pembangunan rusunawa. Menteri dapat menetapkan penerima bantuan di luar lembaga pendidikan tinggi atau lembaga pendidikan berasrama seperti ketentuan di atas setelah mendapat pertimbangan dari Deputi Perumahan Formal. Pembangunan rusunawa USU dilaksanakan sesuai dengan lokasi yang diajukan 
pada proposal pembangunan rusunawa. Setelah mengadakan analisis terhadap proses pembangunan rusunawa USU, didapatkan kesimpulan bahwa pembangunan rusunawa USU sesuai dengan ketentuan yang berlaku. Bangunan rusunawa dibangun dengan menggunakan DED prototipe dari Kementrian Negara Perumahan Rakyat, disesuaikan dengan kondisi dan kebutuhan rusunawa USU. Proses pembangunan ini diawasi oleh pihak Kementrian Negara Perumahan Rakyat dan pihak dari USU.

Pembangunan rusunawa UMA dimulai pada tahun 2007 setelah persetujuan terhadap proposal oleh Kementrian Negara Perumahan Rakyat. Sesuai dengan pengajuan proposal, bangunan rusunawa menggunakan DED prototipe rusunawa mahasiswa. Dalam pembangunannya, pihak Kementrian sebagai pelaksana dan pihak universitas kurang mengadakan koordinasi sehingga bangunan rusunawa yang terbangun dirasakan kurang sesuai dengan yang dibutuhkan oleh universitas. Dari analisa terhadap proses pembangunan fisik dan pemanfaatan ruang rusunawa mahasiswa penulis dapat menyimpulkan bahwa pada umumnya ketiga rusunawa memperoleh nilai yang setara. Hal ini disebabkan pada pembangunan rusunawa yang melalui mekanisme bantuan pembangunan rusunawa dari Kementrian Negara Perumahan Rakyat sudah ada prototipe bangunan tertentu yang bisa digunakan apabila pihak perguruan tinggi tidak memiliki gambar rancang bangun sendiri. Untuk pemanfaatan ruang juga mengikuti standar yang ditentukan oleh DED dari Kementrian Negara Perumahan Rakyat.

\section{Analisa Terhadap Efektifitas Kebijakan}

Dalam mengukur efektifitas implementasi kebijakan tersebut, peneliti menggunakan 4 (empat) kategori penilaian yaitu: 1) komunikasi antar pelaksana kebijakan; 2) sumber daya manusia; 3) disposisi; dan 4) struktur birokrasi.

Komunikasi antara pelaksana kebijakan, dalam hal ini adalah antara pihak USU dan IAIN Sumatera Utara dengan pihak Kementrian Negara Perumahan Rakyat. Dari hasil wawancara dengan narasumber, terjalin komunikasi yang baik antara pihak pembangun dan universitas. Hal ini menyebabkan proses bantuan pembangunan rusunawa yang lancar dan optimal karena setiap permasalahan bisa dicari pemecahan yang baik untuk kedua belah pihak. Pihak lembaga pendidikan tinggi menetapkan suatu susunan panitia yang khusus menangani dan mengawasi proses permohonan bantuan pembangunan rusunawa hingga proses pembangunan fisik rusunawa. Dari segi sumber daya manusia, kuantitas dan kualitas pelaksana kebijakan dalam hal ini pihak Kementrian Negara Perumahan Rakyat dan lembaga pendidikan tinggi yaitu USU, UMA dan IAIN Sumatera Utara, dinilai memadai. Pihak Kementrian Negara Perumahan Rakyat menyiapkan petugas-petugas di lapangan sebagai wakil dari kementrian yang mengawasi jalannya pembangunan rusunawa mahasiswa sehingga pelaksanaan pembangunan dapat berjalan lancar. Pihak universitas telah mengimplementasikan kebijakan-kebijakan yang telah digariskan oleh pembuat kebijakan mulai dari proses pengajuan proposal bantuan pembangunan rusunawa mahasiswa dengan menempatkan orang-orang yang berkompeten di bidangnya sebagai wakil pihak universitas yang menangani bantuan pembangunan rusunawa mahasiswa tersebut. Para pelaksana kebijakan di lapangan baik pihak kementrian maupun universitas berkomitmen untuk menjalankan tugas dengan sebaik-baiknya. Semua kebijakan yang telah digariskan baik oleh undang-undang maupun peraturan-peraturan lainnya, diimplementasikan dalam pekerjaan di lapangan sehingga pembangunan rusunawa mahasiswa USU, UMA dan IAIN Sumatera Utara terlaksana dengan baik dan optimal pemanfaatannya. Kementrian Negara Perumahan Rakyat telah mensosialisasikan proses pengajuan bantuan pembangunan rusunawa mahasiswa kepada seluruh perguruan tinggi di Indonesia dan menjelaskan mekanisme pengajuan bantuan. USU, UMA dan IAIN Sumatera Utara sebagai pemohon bantuan tidak menghadapi proses birokrasi yang berbelit-belit dalam pengajuan bantuan hingga proses pembangunan rusunawa. Struktur birokrasi yang sederhana namun sesuai dengan kebijakan yang ditetapkan, mempermudah pihak universitas dalam proses pengajuan bantuan pembangunan rusunawa 
mahasiswa. Hal ini mempermudah pihak universitas untuk mengimplementasikan kebijakan dalam pelaksanaan di lapangan. Hasil analisa terhadap keempat parameter penilaian efektifitas implementasi kebijakan bantuan pembangunan rusunawa mahasiswa diperoleh kesimpulan sebagai berikut:

1. Komunikasi Pemanfaatan Bantuan dan Bangunan

Kebijakan, dalam hal ini Pemerintah yang diwakili oleh Kementrian Negara Perumahan Rakyat dengan lembaga perguruan tinggi memiliki hasil yang berbeda. Untuk USU dan IAIN, masing- masing memiliki tingkatan komunikasi yang bagus dengan kementrian. Namun dari hasil wawancara dengan pihak UMA, diperoleh hasil bahwa komunikasi antara kementrian dengan universitas tidak begitu baik. Pihak UMA tidak begitu dilibatkan dalam proses pelaksanaan pembangunan rusunawa sehingga ada kesenjangan dalam pengambilan keputusan.

2. Sumber daya manusia

Sumber daya manusia yang disiapkan dalam proses bantuan pembangunan rusunawa pada dasarnya tidak mengalami kendala yang berarti. Baik Kementrian Negara Perumahan Rakyat maupun ketiga lembaga pendidikan tinggi telah menempatkan orang-orang yang berkompeten di bidangnya masing- masing. Dalam hal ini, Kementrian Negara Perumahan Rakyat menugaskan Deputi Perumahan Formal sebagai pelaksana kebijakan di lapangan. Sedangkan pihak lembaga perguruan tinggi membentuk panitia khusus yang terdiri dari staf dan akademisi.

\section{Disposisi}

Masing-masing pelaksana kebijakan memiliki komitmen dalam mengimplementasikan kebijakan bantuan pembangunan rusunawa mahasiswa. Hal ini ditunjukkan dengan memenuhi seluruh tahapan proses pemberian bantuan sesuai dengan undang-undang dan peraturan yang berlaku.

4. Struktur birokrasi

Dalam melaksanakan kebijakan bantuan pembangunan rusunawa mahasiswa, Kementrian Negara Perumahan Rakyat menyusun struktur birokrasi yang tidak berbelit-belit. Proses permohonan bantuan, pembangunan hingga serah terima bangunan rusunawa dilaksanakan melalui birokrasi yang sistematis.

5. Komunikasi antara para pelaksanaRusunawa Mahasiswa.

Bantuan pembangunan rusunawa mahasiswa pada tiap-tiap lembaga pendidikan tinggi yang menjadi obyek penelitian pada sudah dimanfaatkan dengan baik namun kurang optimal. Dengan memanfaatkan dana bantuan, rusunawa mahasiswa di tiap-tiap lembaga pendidikan tinggi sudah terbangun dan sebagian sudah dihuni. Desain rusunawa berupa penyeragaman desain rusunawa mahasiswa dari pihak pemberi bantuan dalam hal ini Kementerian Perumahan Rakyat. Hal ini menyebabkan adanya kesenjangan antara kebutuhan penerima dana dengan kondisi bangunan rusunawa terbangun. Namun untuk pemanfaatan dana bantuan, tidak ada masalah yang berarti. Dana yang diberikan oleh pemberi bantuan dapat tersalurkan dengan baik dan diwujudkan dalam bentuk bangunan rusunawa mahasiswa.

\section{KESIMPULAN}

Dari hasil penelitian terhadap efektifitas implementasi kebijakan bantuan pembangunan rusunawa pada lembaga pendidikan tinggi di kota Medan, setelah menelaah proses pengajuan proposal, pembangunan fisik hingga serah terima, didapatkan kesimpulan bahwa implementasi kebijakan tersebut belumlah efektif. Sosialisasi yang kurang aktif dari pihak Kementrian Negara Perumahan Rakyat kepada seluruh perguruan tinggi di Indonesia, untuk memperjelas persyaratan dan jenis bantuan yang diberikan sehingga ada kesan bantuan pembangunan rusunawa mahasiswa dari Pemerintah kurang memperhatikan kebutuhan pihak penerima bantuan seperti spesifikasi teknis yang diinginkan atau dibutuhkan oleh rusunawa perguruan tinggi yang tidak bisa disamaratakan antara satu perguruan tinggi dengan perguruan tinggi yang lain.

Selain itu proses penghunian rusunawa terhambat karena tertundanya serah terima bangunan padahal secara fisik rusunawa telah siap huni, dalam hal ini Rusunawa UMA dan IAIN. Menurut hasil wawancara dengan pihak 
UMA, hal ini disebabkan spesifikasi teknis bangunan tidak sesuai dengan yang diharapkan sehingga universitas tidak dapat menyediakan meubeler rusunawa. Bangunan yang seharusnya sudah dapat dimanfaatkan menjadi terbengkalai dan sedikit demi sedikit mengalami kerusakan.

Pada dasarnya hal-hal di atas terjadi karena komunikasi antara pelaksana kebijakan masih kurang baik. Kedua pihak seharusnya mengadakan koordinasi secara berkala untuk mengetahui kewajiban dan hak masing-masing. Di sisi lain, penilaian efektifitas berdasarkan sumber daya manusia, disposisi dan struktur birokrasi tidak mengalami hambatan, kedua pelaksana kebijakan telah melaksanakan ketiga hal tersebut dengan baik sesuai dengan peraturan yang berlaku.

Sebelum suatu kebijakan dibuat dan diimplementasikan sebaiknya Pemerintah terlebih dahulu melaksanakan sosialisasi kepada perguruan tinggi sebagai kelompok sasaran, baik dari teknis dan non teknis karena setiap lokasi memiliki karakteristik yang tidak sama, terutama antara propinsi yang berbeda. Hal ini sangat perlu agar pihak perguruan tinggi manapun paham tentang manfaat yang dapat diperoleh dan resiko yang harus ditanggung dari ketentuan yang ada yang akan dilaksanakan. Kesepahaman ini tentu saja akan mengurangi resiko benturan yang terjadi antara Pemerintah dan perguruan tinggi, sehingga pembangunan dapat berjalan dengan lancar tanpa suatu hambatan yang berarti.

Bagi perguruan tinggi, kebijakan bantuan pembangunan rusunawa harus bisa memberikan gambaran tentang kewajiban dan hak apa saja yang dimiliki oleh perguruan tinggi secara keseluruhan sehingga perguruan tinggi dapat mempersiapkan hal-hal yang tidak dicakup dalam bantuan pembangunan rusunawa mahasiswa. Dengan demikian, pihak perguruan tinggi tidak menyerahkan sepenuhnya kewajiban kepada pihak Pemerintah dalam hal pembangunan rusunawa mahasiswa.

\section{DAFTAR PUSTAKA}

Abidin, S.Z. (2006) Kebijakan Publik, Jakarta: Suara Bebas

Akon, dan Riduwan (2009) Aplikasi Statistik dan Metode Penelitian Untuk Administrasi dan Manajemen, Bandung: Dewa Ruci.

Alie, A. (2006) Identifikasi Kebijakan Dalam Pembiayaan Pemeliharaan Jalan Kabupaten Dalam Kota Sungailiat di Kabupaten Bangka, Tugas Akhir tidak diterbitkan, Program Studi Perencanaan Wilayah dan Kota, Fakultas Teknik Universitas Diponegoro, Semarang.

Dunn, William (1998) Pengantar Analisis Kebijakan Publik, Yogyakarta: Gadjah Mada University Press.

Dwijowijoto, R.N. (2003) Kebijakan Publik: Formulasi Implementasi dan Evaluasi, Jakarta: Elex Media Komputindo.

Goggin, Malcolm L. Ann O’M. Bowman. James P.Lester. Laurence J.O'Toole,Jr. (1990) Implementation Theory and Practice toward a Third Generation. Glenview,Illinois - London, England: A Division of Scott, Foresman and Company.

Isworo, W.I. (1996). Beberapa Pendekatan dalam Analisis dan Implementasi Kebijakan. Jakarta: PT. Rajawali Grafindo Persada.

Peraturan Menteri Negara Perumahan Rakyat

Nomor 9 Tahun 2008 tentang Bantuan

Pembangunan Rumah Susun Sederhana

Sewa (Rusunawa) pada Lembaga Pendidikan Tinggi dan Lembaga Pendidikan Berasrama.

Peraturan Menteri Pekerjaan Umum Nomor 60/PRT/1992 tentang Persyaratan Teknis Pembangunan Rumah Susun.

Undang-Undang No.16 Tahun 1985 tentang Rumahsusun 